\title{
С.М. Кочои*
}

\section{ПРИВЛЕЧЕНИЕ ЗАВЕДОМО НЕВИНОВНОГО К УГОЛОВНОЙ ОТВЕТСТВЕННОСТИ: ВОПРОСЫ ПРАВА И ПРОЦЕССА}

\begin{abstract}
Ключевые слова. Преступления против правосудия; привлечение заведомо невиновного к уголовной ответственности; возбуждение уголовного дела; уголовное преследование; субъект совершения преступления, предусмотренного ст. 299 УК РФ; момент окончания преступления, предусмотренного ст. 299 УК РФ; практика применения ст. 299 УК РФ; совериенствование ст. 299 УК РФ.
\end{abstract}

Уголовный кодекс РФ (далее - УК) привлечение заведомо невиновного к уголовной ответственности относит к преступлениям против правосудия (ст. 299) ${ }^{1}$. Сравнение данной нормы с соответствующими нормами Уголовно-процессуального кодекса РФ (далее - УПК) показывает, что между ними существуют неоправданные терминологические расхождения. УПК (в частности, глава 4 и раздел VII) говорит о «возбуждении уголовного дела», а не «привлечении к уголовной ответственности». Очевидно, что название (и диспозиция) ст. 299 УК должно соответствовать уголовно-процессуальным нормам и быть сформулировано следующим образом: «Возбуждение уголовного дела в отношении заведомо невиновного лица». В литературе, правда, по этому вопросу имеются и другие предложения. Например, согласно одному из них, в ст. 299 УК категорию «уголовная ответственность» следует

(C) Кочои С.М., 2012.

* Доктор юридических наук, профессор кафедры уголовного права Московской государственной юридической академии имени О. Е. Кутафина, заслуженный работник высшей школы РФ. [sam.kochoi@bk.ru]

1 Как известно, правосудие в РФ осуществляется только судом (ч. 1 ст. 118 Конституции РФ), поэтому рассматриваемое преступление, с формальной точки зрения, не может быть непосредственно направлено против правосудия. Не случайно в отдельных странах, в уголовном законодательстве которых есть аналогичный состав преступления, он отнесен к разряду должностных преступлений. Например, УК ФРГ включил § 344 «Преследование невиновного» в раздел «Должностные преступные деяния»; УК КНР включил ст. 399 об уголовном преследовании заведомо невиновного лица в главу «Преступления против интересов государственной службы» и т. д. 
заменить на категорию «уголовно-процессуальное преследование» ${ }^{2}$. Однако УПК (п. 55 ст. 5) содержит понятие «уголовное преследование» (а не «уголовно-процессуальное преследование»), и оно более широкое («процессуальная деятельность, осуществляемая стороной обвинения в целях изобличения подозреваемого, обвиняемого в совершении преступления), нежели используемое в УПК другое понятие - «возбуждение уголовного дела».

Субъектом рассматриваемого преступления признается лицо, наделенное законом правом привлечения к уголовной ответственности. В уголовноправовой литературе принято считать, что таким лицом являются только дознаватель и следователь. При этом, как подчеркивает А. И. Чучаев, ответственность по ст. 299 УК «несет не руководитель органа дознания, а то лицо, которое непосредственно осуществляет дознание и выносит заведомо незаконное постановление о привлечении к уголовной ответственности» ${ }^{3}$. Однако подобное мнение не учитывает в полной мере соответствующие положения уголовно-процессуального законодательства.

Согласно ч. 1 ст. 145 УПК, лицом, наделенным правом принимать решение о возбуждении уголовного дела, может быть орган дознания, дознаватель, следователь, руководитель следственного органа. Как видим, в этом перечне присутствуют как орган власти (орган дознания), так и должностные лица (дознаватель, следователь, руководитель следственного органа) ${ }^{4}$.

Статья 145 УПК оговаривает, что перечисленные выше лица и орган (по результатам рассмотрения сообщения о преступлении) принимают решение о возбуждении уголовного дела в порядке, установленном ст. 146 УПК, то есть по делам публичного обвинения. По делам частного обвинения они только направляют сообщение в суд (ч. 2 ст. 147 УПК). Однако, если заявление подано в отношении лица, данные о котором потерпевшему не известны, то мировой судья отказывает в принятии заявления к своему производству и направляет указанное заявление руководителю следственного органа или начальнику органа дознания для решения вопроса о возбуждении уголовного дела, о чем уведомляет лицо, подавшее заявление. Фактически же это, по нашему мнению, означает (когда заявление подано в отношении лица, данные о котором потерпевшему известны), что суд превращен в орган, имеющий право возбуждать уголовное дело.

2 Лебедев А. Г. Привлечение заведомо невиновного к уголовной ответственности по уголовному праву России: автореф. дис. ... канд. юрид. наук. Саратов, 2004 [Электронный ресурс]. Доступ из Справ.-правовой системы «КонсультантПлюс».

3 См., напр.: Уголовное право. Особенная часть: учебник для бакалавров / под ред. А. И. Чучаева. М.: Проспект. 2012. С. 417.

4 При этом если руководитель следственного органа частью 1 ст. 145 УПК прямо отнесен к лицам, имеющим право возбуждать уголовное дело, то руководитель (начальник) подразделения дознания почему-то - нет (хотя ч. 2 ст. $40^{1}$ УПК последнему такое право и предоставляет). Очевидно, речь здесь идет о законодательном пробеле. 
В уголовно-процессуальной литературе отмечается, что «суд не имеет право возбуждать дела публичного обвинения» ${ }^{5}$. В случае же с делами частного обвинения возбуждение происходит не непосредственно судом, а «путем подачи ... потерпевшим или его законным представителем заявления в суд» (ч. 1 ст. 318 УПК), «то есть так же как бы не судом» ${ }^{6}$. Однако это лишь подтверждает наше вышеизложенное мнение.

Что касается уголовных дел частнопубличного обвинения, то производство (включая досудебное) по ним ведется в общем порядке (ч. 3 ст. 147 УПК). Таким образом, субъектом привлечения к уголовной ответственности заведомо невиновного (возбуждения уголовного дела), по нашему мнению, могут быть признаны: орган дознания (в лице его начальника, понятие которого раскрывается в п. 17 ст. 5 УПК), дознаватель, следователь, руководитель следственного органа, а также мировой судья.

Как показывают статистические данные, количество таких преступлений, как привлечение заведомо невиновного к уголовной ответственности, мизерное 7 . Изучение опубликованной практики применения ст. 299 УК показывает, что она испытывает сложности с применением как соответствующего процессуального, так и материального права. Например, по делу старшего лейтенанта милиции Подгорновой возник вопрос о том, можно ли привлекать ее (следователя) к ответственности по ст. 299 УК, если имеется неотмененное постановление суда (о прекращении уголовного дела за примирением сторон), которым установлено, что потерпевший (привлеченное Подгорновой незаконно к уголовной ответственности лицо) виновен в совершении преступления ${ }^{8}$. Суд, рассмотревший данное дело, дал утвердительный ответ. Однако следует напомнить, что Конституционный Суд РФ признал ряд законодательных положений не соответствующими Конституции РФ, в той мере, в какой этими положениями допускается возбуждение в отношении судьи уголовного дела по признакам преступления, предусмотренного статьей 305 УК РФ, «в случае, когда соответствующий судебный акт, вынесенный этим судьей, вступил в законную силу и не отменен в установленном процессуальным законом

5 Смирнов А. В., Калиновский К. Б. Комментарий к Уголовно-процессуальному кодексу Российской Федерации. М., 2009 [Электронный ресурс]. Доступ из Справ.правовой системы «КонсультантПлюс».

6 Рыжаков А.П. Комментарий к Уголовно-процессуальному кодексу Российской Федерации (постатейный). Подготовлен для СПС «КонсультантПлюс». М., 2010 [Электронный ресурс]. Доступ из Справ.-правовой системы «КонсультантПлюс».

7 Можно, пожалуй, согласиться с А. В. Наумовым, по мнению которого такая статистика «вряд ли соответствует действительному положению вещей; СМИ свидетельствуют о многочисленных фактах совершения подобных преступлений»// Наумов A. B. Российское уголовное право. Курс лекций. В 2-х томах. Том 2. Особенная часть. М.: Юридическая литература. 2004, С. 688.

8 Кассационное Определение Верховного Суда РФ от 20.06.2012 № 37-О12-9сп [Электронный ресурс]. Доступ из Справ.-правовой системы «КонсультантПлюс». 
порядке» ${ }^{9}$. Таким образом, как мы считаем, в деле Подгорновой также следовало вначале отменить в установленном УПК порядке вышеуказанное постановление суда, и лишь затем решать вопрос о возбуждении против нее уголовного дела. Именно подобным образом был решен вопрос, например, по делу лейтенанта милиции Суетина. Суд не согласился с представлением прокуратуры о его необоснованном оправдании по ч. 1 ст. 299 УК, поскольку в деле имелся неотмененный приговор об осуждении П. (привлеченного Суетиным к уголовной ответственности $)^{10}$.

Кстати, по делу Подгорновой стороной защиты было высказано мнение о том, что если привлечение заведомо невиновного к уголовной ответственности, а также фальсификация доказательств являлись способом совершения другого преступления - незаконного освобождения от уголовной ответственности, то их самостоятельная квалификация не требуется. На наш взгляд, суд правильно не согласился с защитой, поскольку правовых оснований для такого поглощения нет никаких.

Судя по материалам опубликованной практики, нередко суды оправдывают лиц, привлеченных к ответственности по ст. 299 УК. Так, по делу Садовниковой (осужденной по ч. 2 ст. 303 УК) судебные инстанции не согласились с представлением прокуратуры о необоснованности оправдания ее по ч. 1 ст. 299 УК, указав на то, что установленные по делу обстоятельства «свидетельствуют об отсутствии прямого умысла Садовниковой на привлечение к уголовной ответственности заведомо невиновного» ${ }^{11}$. Однако означает ли это, что постановление о привлечении конкретного лица к уголовной ответственности она могла выносить по неосторожности? Признаться, трудно в это поверить.

В практике неоднозначно решается вопрос о квалификации по совокупности преступлений, предусмотренных статьями 285 или 286 и 299 УК. По делу 3., признанного виновным в том, что работая старшим дознавателем отдела дознания ОВД, превысил должностные полномочия, незаконно освободил от уголовной ответственности С., задержанного с наркотическим средством «марихуана», и вместо него незаконно привлек к уголовной ответственности заведомо невиновного Г., Верховный Суд РФ справедливо исключил из квалификации его действий ч. 1 ст. 286 УК, поскольку «такое превышение должностных полномочий предусмотрено специальными нормами, а именно ст. ст. 299, 300 УК РФ, по которым 3. осужден судом, дополнительной квалификации содеянного по совокупности со ст. 286 ч. 1 УК РФ не требуется» ${ }^{12}$.

9 Определение Конституционного Суда РФ от 18 октября 2011 года № 23-П [Электронный ресурс]. Доступ из Справ.-правовой системы «КонсультантПлюс».

10 Кассационное определение Верховного Суда РФ от 06.09.2004 по делу № 44-004-122 [Электронный ресурс]. Доступ из Справ.-правовой системы «КонсультантПлюс».

11 Определение Верховного Суда РФ от 22.12.2008 № 48-О08-115 [Электронный ресурс]. Доступ из Справ.-правовой системы «КонсультантПлюс».

12 Определение Верховного Суда РФ от 18.09.2008 № 5-О08-167 [Электронный ресурс]. Доступ из Справ.-правовой системы «КонсультантПлюс». 
Однако в случаях, когда виновным инкриминируют наряду с совершением преступления, предусмотренного ст. 299 (300, 303), также преступление, предусмотренное ст. 285 УК, квалификация содеянного является противоречивой. Так, по делу Эльбанова, осужденного в том числе по ч. 1 ст. 299, ч. 2 ст. 303 и ч. 1 ст. 285 УК, вопрос об исключении последней статьи из квалификации не был даже поставлен ${ }^{13}$, тогда как по делу Телятова Верховный Суд РФ пришел к выводу, что нижестоящий суд неправильно применил уголовный закон, «квалифицировал по совокупности преступлений одни и те же деяния должностного лица, предусмотренные общей (ст. 285 УК РФ) и специальной нормами (ст. 303 УК РФ), без учета того, что последняя норма представляет частный случай злоупотребления служебными полномочиями специального должностного лица» ${ }^{14}$.

Данный пример, кстати, вызывает еще один вопрос: привлечение заведомо невиновного к уголовной ответственности - это разновидность злоупотребления должностными полномочиями или превышения должностных полномочий? Нам представляется, что оно - специальный вид превышения должностных полномочий, конструктивным признаком которого является совершение действий, явно выходящих за пределы служебной компетенции должностного лица.

Нет единства в теории и практике также по вопросу о моменте окончания преступления, предусмотренного ст. 299 УК. В уголовно-правовой литературе утверждается, что данное преступление окончено с момента «подписания компетентным лицом постановления о привлечении в качестве обвиняемого» ${ }^{15}$. Однако по уже упомянутому делу Телятова Верховный Суд РФ обратил внимание на то, что «в соответствии со ст. 225 УПК РФ привлечение лица к уголовной ответственности определяется обвинительным актом. При этом обвиняемый, его защитник должны быть ознакомлены с обвинительным актом и материалами уголовного дела, о чем делается соответствующая отметка в протоколе ознакомления с материалами дела» ${ }^{16}$. А поскольку в данном конкретном случае они не были осведомлены о вынесенных в их отношении названных процессуальных документах и о привлечении их к уголовной ответственности, суд расценил сам факт изготовления обвинительного акта как приготовление к преступлению. «Действующее законодательство (п. 2 ч. 1 ст. 47, ст. 225 УПК РФ), - указал Верховный Суд РФ, - к процессуальным основаниям признания лица обвиняемым относит не только постановление о привлечении в качестве обвиняемого, но и обвинительный акт...Обвинительный акт является формой объединения в

13 Кассационное Определение Верховного Суда РФ от 05.07.2005 № 21-О05-5 [Электронный ресурс]. Доступ из Справ.-правовой системы «КонсультантПлюс».

14 Определение Верховного Суда РФ от 13.09.2007 по делу № 47-007-46 [Электронный ресурс]. Доступ из Справ.-правовой системы «КонсультантПлюс».

15 Комментарий к Уголовному кодексу Российской Федерации / под ред. В. Т. Томина, В. В. Сверчкова. М.: Юрайт, 2009. С. 1141.

16 Определение Верховного Суда РФ от 13.09.2007 по делу № 47-007-46 [Электронный ресурс]. Доступ из Справ.-правовой системы «КонсультантПлюс». 
одном документе постановления о привлечении в качестве обвиняемого и обвинительного заключения. Однако официальным процессуальным документом он становится после его предъявления обвиняемому, поскольку в силу ст. 47 УПК РФ обвиняемый вправе знать, в чем он обвиняется, получить копию обвинительного акта, возражать против обвинения, а в соответствии с п. 22 ст. 5 УПК РФ обвинение - это утверждение о совершении определенным лицом деяния, запрещенного уголовным законом, выдвинутое в порядке, установленном УПК РФ. Само по себе составление обвинительного акта не может рассматриваться как оконченное преступление, предусмотренное ст. 299 УК РФ, поскольку на данной стадии возможен предусмотренный ст. 31 УК РФ добровольный отказ, исключающий уголовную ответственность. В этой связи не могут быть признаны состоятельными доводы кассационного представления о том, что Телятовым Р.А. была полностью выполнена объективная сторона преступления, предусмотренного ст. 299 УК РФ, которое, по мнению государственного обвинителя, окончено с момента изготовления и утверждения обвинительного акта ${ }^{17}$ ».

Последние наши замечания касаются возможностей совершенствования ст. 299 УК. Во-первых, следует усилить ответственность в случае совершения преступления из корыстных побуждений. «Широкая распространенность фактов возбуждения “заказных” уголовных дел, связанных с корыстной мотивацией, или иной личной заинтересованности (а также опыт российского и зарубежного законодательства), - пишет Н. А. Будяков, - обуславливает целесообразность придания им роли квалифицирующего признака» ${ }^{18}$. Во-вторых, необходимо обратить внимание на санкции, которые в ст. 299 УК не менялись ни разу. Их следует сделать альтернативными (как, например, в ст. 301 УК) и согласовать с санкциями смежных норм (прежде всего, статей 300 и 301 УК).

Материал поступил в редакичию 27 августа 2012 года.

17 Определение Верховного Суда РФ от 13.09.2007 по делу № 47-007-46 [Электронный ресурс]. Доступ из Справ.-правовой системы «КонсультантПлюс».

18 «Широкая распространенность фактов возбуждения «заказных» уголовных дел, связанных с корыстной мотивацией, или иной личной заинтересованности (а также опыт российского и зарубежного законодательства), - пишет Н. А. Будяков, - обуславливает целесообразность придания им роли квалифицирующего признака»//Будяков Н. A. Привлечение заведомо невиновного к уголовной ответственности (ст. 299 УК), незаконное освобождение от уголовной ответственности (ст. 300 УК): теоретически аспекты, проблемы законодательного описания составов и квалификации: автореф. дис. ... канд. юрид. наук. Краснодар, 2007 [Электронный ресурс]. Доступ из Справ.-правовой системы «КонсультантПлюс». 